Key words: motor vehicle, driver, statistics, road traffic accident (RTA), mortality rate, Department of Patrol Police, Service Center of the Ministry of Internal Affairs of Ukraine.

DOI https://doi.org/10.33766/2524-0323.86.246-257

УДК 343.98

М. А. Готвянська, аспірантка Донецького юридичного інституту МВС України (м. Кривий Ріг, Україна) e-mail: postmaster@dli.donetsk.ua iD https://orcid.org/0000-0002-0246-4621

\title{
ТАКТИКА ДОПИТУ НЕПОВНОЛІТНЬОГО, ВТЯГНУТОГО У ЗЛОЧИННУ ДІЯЛЬНІСТЬ (ОКРЕМІ АСПЕКТИ)
}

У статті розглянуто окремі аспекти тактики допиту неповнолітнього, втягнутого в злочинну діяльність. Акцентовано увагу на процесуальних особливостях допиту неповнолітньої особи, висвітлено проблеми, 3 якими стикаються на практиці, а також надано пропозиції щодо їх усунення. Зазначено на важливості підготовчого етапу до допиту, висвітлено тактичні особливості встановлення психологічного контакту 3 неповнолітнім, рекомендовано максимальне використання можливостей вільної розповіді. Звернено увагу на роль криміналістичних знань під час допиту.

Ключові слова: кримінальне провадження, тактика допиту неповнолітнього, дорослий, криміналістичні рекомендації, втягнення в злочинну діяльність.

Постановка проблеми. Однією 3 розповсюджених слідчих (розшукових) дій при розслідуванні будь-яких правопорушень є допит. Метою його проведення є отримання повних та правдивих показань про події та факти, що мають значення для встановлення істини в кримінальному провадженні. Саме допит у багатьох випадках є основним джерелом отримання інформації про подію, що сталась, і показання свідків або потерпілих, наряду з іншими доказами, нерідко покладаються в основу висновку про причини події та винність конкретних осіб. Разом із тим, незважаючи на очевидну інформаційну значимість допиту, слідчі іноді підходять до його проведення без достатньої відповідальності та припускаються помилок, які негативно впливають на подальший хід розслідування. У нашому випадку ситуацію підсилює ще й той факт, що по деяких правопорушеннях фігурують неповнолітні, допит яких оминути неможливо. I хоча певні рекомендації щодо тактики їх допиту розроблені криміналістичною наукою, проте вони практично залишилися поза увагою науковців щодо злочинів, пов'язаних із втягненням неповнолітніх у злочинну діяльність. 
Аналіз останніх досліджень і публікацій. Значна кількість науковців торкалися різних сторін допиту під кутом зору мети своїх досліджень, серед яких є наступні: Л. Є. Ароцкер, В. П. Бахін, О. Я. Баєв, Р. С. Бєлкін, О.М. Васильєв, Л. М. Карнеєва, В. Г. Лукашевич, М. І. Порубов, О. Б. Соловйов, В. М. Стратонов, В. М. Шевчук, Ю. А. Чаплинська, У. А. Усманов та ін. 3 різних аспектів допиту свого часу були захищені дисертації В. О. Коноваловою (1953), О. О. Закатовим (1971), В. С. Комарковим (1973), В. Є. Богинським (1980), М. В. Бахарєвим (1981), В. А. Журавлем (1983), В. Ю. Шепітьком (1991), В. К. Весельським (1999), Н. В. Грищенко (2012). Безпосредньо питанням допиту саме по злочинах, пов'язаних із втягненням неповнолітніх у злочинну діяльність частково, свої наукові напрацювання присвячували М. М. Сидорін (1972), Н. В. Шость (1973), К. К. Сперанський (1993), О. В. Кушпель (1998), О. М. Сажаєв (2002), Д. В. Флоря (2002), О. В. Полікашина (2003), О. В. Сокол (2006), Ю. В. Лисюк (2006), О. Г. Предместніков (2009), Т. П. Матюшкова (2006), Є. О. Селезньова (2007), О. В. Яцечко (2007), Ю. В. Сокол (2012) та ін. Наукові доробки зазначених учених стали фундаментом для подальших наукових досліджень у цьому напрямку.

Формування цілей. Метою статті є висвітлення окремих аспектів тактики допиту неповнолітніх осіб, втягнених у злочинну діяльність.

Виклад основного матеріалу. За своєю сутністю будь-який допит - це процесуальна дія, яка являє собою регламентований кримінальнопроцесуальними нормами інформаційно-психологічний процес спілкування осіб, котрі беруть у ньому участь, та спрямована на отримання інформації про відомі допитуваному факти, що мають значення для встановлення істини у кримінальному провадженні $[1$, с. 256; 2, с. 360]. На думку В. М. Тертишника, допит - це слідча дія, у процесі якої слідчий отримує від особи, яка володіє відомостями, що мають значення в кримінальній справі (свідка, потерпілого, експерта, підозрюваного або обвинуваченого), словесну інформацію про обставини події злочину та інші факти, які мають значення для встановлення об'єктивної істини й забезпечення правильного застосування закону [3, с. 506]. Складний i багатогранний характер допиту неповнолітніх (незалежно від їх процесуального статусу) полягає в тому, що він охоплює собою процесуальний, тактичний, організаційний, психологічний, педагогічний та етичний аспекти [4, с. 3]. Наведене прямо впливає на діяльність слідчого і знаходить своє відображення в тому, що останній використовує тактичні прийоми в суворій відповідності до вимог кримінального процесуального законодавства та норм моральності з урахуванням вікових, психологічних та індивідуальних особливостей особистості неповнолітнього. До того ж, творчий підхід, володіння та вміння інтерпретувати та використовувати законні заходи впливу на допитувану особу створюють криміналістичну платформу на отримання позитивних результатів під час проведення такого різновиду слідчої (розшукової) дії, як допит малолітньої або неповнолітньої особи.

У відповідності до ст. 1 Конвенції ООН про права дитини від 20 листопада 1989 року [5], що була ратифікована постановою ВР УРСР № 789 - 
XII від 27 лютого 1991 року, дитиною є кожна людська істота до досягнення 18-річного віку, якщо за законом, вона не досягає повноліття раніше. Аналогічний підхід до визначення поняття «дитина» було запроваджено і в ст. 1 Закону України «Про охорону дитинства» від 26.04.2001р. [6], за яким такою визнається особа віком до 18 років (повноліття), якщо згідно із законом, застосованим до неї, вона не набуває прав повнолітньої раніше. У той же час у галузі кримінального процесуального законодавства України (як і у вітчизняному цивільному праві) діти (особи, які не досягли 18 років) представлені двома категоріями - малолітніми та неповнолітніми. Так згідно п. 11 ч. 1 ст. 3 кримінального процесуального кодексу України (надалі КПК), малолітньою особою є дитина до досягнення нею чотирнадцяти років, а неповнолітньою, у відповідності до п. 12 ч. 1 ст. 3 КПК України, є малолітня особа, а також дитина віком від чотирнадцяти до вісімнадцяти років [7]. Більше того, у сфері кримінального провадження України не вбачається підстав вважати повнолітньою особу, що набула повної цивільної дієздатності в разі реєстрації шлюбу до вісімнадцяти років (ч. 2 ст. 34 ЦК України); особу, яка досягла шістнадцяти років і працює за трудовим договором, а також неповнолітню особу, яка записана матір'ю або батьком дитини (ч. 1 ст. 35 ЦК України )[8], оскільки сам КПК не встановлює жодних винятків, у тому числі й щодо мінімального віку, з якого особа може бути допитана в якості свідка або потерпілого. Усі вищезазначені особи до досягнення вісімнадцятирічного віку $є$ неповнолітніми в системі кримінальних процесуальних правовідносин i, відповідно, користуються всіма додатковими гарантіями, передбаченими КПК України [10, с. 3; 7, c. 568]. Зокрема, допиту малолітніх або неповнолітніх учасників кримінального провадження присвячено такі статті КПК, як ст. 226, що має назву «Особливості допиту малолітньої або неповнолітньої особи»; ст. 227 «Участь законного представника, педагога, психолога або лікаря у слідчих (розшукових) діях за участю малолітньої або неповнолітньої особи», а також ст. 490 - «Допит неповнолітнього підозрюваного чи обвинуваченого» та ст. 491 - «Участь законного представника, педагога, психолога або лікаря в допиті неповнолітнього підозрюваного чи обвинуваченого».

3 іншого боку, відповідно до ч. 5 ст. 40 КПК, слідчий є самостійним у своїй процесуальній діяльності, i особам, що не мають на те законних повноважень, втручання забороняється. У той же час слід враховувати й той факт, що слідчий не може бути всебічно обізнаний з усіх галузей людської діяльності та досконало володіти всіма спеціальними знаннями, з огляду на що законодавець надає йому право використовувати знання інших спеціалістів. Більше того, КПК України містить норми, які не лише надають право, а й вимагають обов' язкової участі певних спеціалістів (законодавець їх називає за певною професією: педагог, лікар, судово-медичний експерт тощо) при проведенні окремих слідчих (розшукових) дій. Так, відповідно до ч. 1 ст. 226 КПК, участь педагога або психолога є обов'язковою при допиті малолітньої або неповнолітньої особи. Присутність лікаря визначається слідчим з урахуванням розвитку малолітнього чи його захворюваності. Що 
стосується батьків, то, відповідно до криміналістичних рекомендацій, їх присутність має сенс лише тоді, коли вони не є приховувачами злочину, не притягуються самі до відповідальності і не можуть негативно вплинути на малолітню або неповнолітню особу та іï свідчення. Водночас у редакції згадуваної статті відсутні чіткі роз'яснення щодо того, у яких випадках повинно бути забезпечено участь педагога, а в яких - психолога. На практиці найчастіше це питання вирішує безпосередньо слідчий за власною ініціативою або за клопотанням захисника. Разом із тим, якщо слідчий має право запросити будь-якого педагога чи психолога (виділено Г. М.), то чи буде в такому разі очікувана користь від участі при допиті незнайомої для неповнолітнього людини (хоча й згадуваного фаху)? Як показує практика, якщо неповнолітній навчається в освітньому закладі, то в нього обов' язково $є$ педагог, який його знає. В інших випадках, коли неповнолітній ніде не навчається, доречніше буде запросити його колишнього педагога або психолога, який коли-небудь підтримував із підлітком контакт. I, як на нашу думку, таке правило слід закріпити в законі. 3 цього питання К. І. Дяченко та Н. В. Шость мають інше бачення, яке полягає в тому, що в разі залучення 3 навчального закладу, в якому навчається чи навчався неповнолітній, педагога, який із неповнолітнім конфліктує, присутність такого матиме лише негативний вплив на проведення допиту [11, с. 13]. Нам імпонує твердження вказаних дослідників, але, на нашу думку, головним чинником під час вибору педагога має бути не тільки фактор взаємодовіри між неповнолітнім і педагогом або психологом, a, у першу чергу, їхні практичний досвід та профільна освіта. Можливо, слід погодитися з В. В. Романюком, який вбачає, що під час вибору між педагогом і психологом (у разі якщо неповнолітній $є$ учнем навчального закладу) перевагу треба віддавати тому педагогу, з яким у дитини є контакт, а в разі відсутності довіри - психологу. Завдяки дотриманню цієї умови можна встановити психологічний контакт, забезпечити доброзичливу атмосферу під час допиту й досягти кращого результату кримінального провадження [12, с. 83].

У свою чергу педагог або психолог мають право з дозволу слідчого ставити питання неповнолітньому, а по закінченню допиту ознайомлювати ся $з$ протоколом і викладати зауваження про правильність і повноту записів у ньому, про що прямо визначено у ч. 2 ст. 227 КПК України. Разом з тим задля мінімізації (або унеможливлення) негативного впливу на неповнолітнього слідчому доцільно завчасно обговорювати з особами, які беруть участь у допиті, загальний тактичний план, роль і ступінь їх участі в допиті неповнолітнього, у тому числі, неприпустимість постановки навідних питань, повчальної інтонації, роздратування та ін. [13, с. 156].

Як відомо, у залежності від віку і психологічного розвитку розрізняють шість груп підлітків: 1) вік немовляти (від народження до року); 2) раннє дитинство (від року до трьох років); 3) дошкільний вік (від трьох до семи років); 4) молодший шкільний вік (від семи до одинадцяти років); 5) підлітки (від 11 до 14-15 років); 6) старший шкільний вік (від 14-15 до 17-18 років). [14, с. 145]. При цьому в літературі визначають, що представники останніх чотирьох груп можуть бути допитаними [15, с. 556]. Звичайно, слідчому 
обов' язково слід враховувати вікові особливості неповнолітніх (незалежно від ïx процесуального положення), серед яких можна виокремити наступні: недостатність життєвого досвіду, схильність до наслідування, намагання в деяких конкретних ситуаціях показати свою перевагу, роль лідера, а також підвищення емоційності й неврівноваженості, імпульсивності, почуття групової підтримки й хибного розуміння дружби, низький рівень самокритики, неадекватне сприйняття й реагування на зміну слідчої ситуації, нерозуміння в повному обсязі своїх процесуальних прав i недооцінка серйозності свого положення, сором' язливості, уразливості тощо.

3 криміналістичної точки зору важливо враховувати той факт, що якщо неповнолітній уже вчиняв той злочин, у який він був втягнений, то слідчий повинен чітко розмежовувати два взаємопов'язані предмети допиту: 1) обставини втягнення дорослим неповнолітнього у вчинення злочину; 2) обставини вчинення неповнолітнім того злочину, у який він був втягнений дорослим.

Серед питань, які підлягають з'ясуванню в процесі допиту неповнолітнього у зв'язку із втягненням його у вчинення злочинну діяльність, можна виділити такі:

1) вік неповнолітнього, склад його сім'ї, взаємовідносини між членами родини, умови проживання, місце навчання (роботи), захоплення, коло спільних з дорослим співучасником знайомих;

2) наявність у неповнолітнього захворювань, травм голови, перебування на обліку в наркологічному, психоневрологічному диспансері (якщо перебуває, то термін і діагноз, а також вид перебування - стаціонарне чи амбулаторне лікування);

3) можливе притягнення неповнолітнього до адміністративної або кримінальної відповідальності;

4) обставини вчинення втягнення (місце, час, обставини втягнення, його способи - умовляння, погрози, обман; надання порад про місце і способи вчинення і приховування злочину та ін.), форм і зміст щодо пропозиції до злочину; можливі протидії з боку неповнолітнього злочинному впливу дорослого тощо);

5) відомості про докази втягнення або джерелах їх отримання: можливі тілесні пошкодження в неповнолітнього (ïх характер, місце знаходження), наявність на одязі слідів діяння дорослого, пошкоджені речі неповнолітнього, письмові повідомлення дорослого; відомості про очевидців і свідків, яким щось відомо про втягнення, відомості про матеріальні засоби втягнення тощо;

6) стан неповнолітнього в момент втягнення, зокрема, можливий стан алкогольного/ наркотичного сп'яніння;

7) причини злочину й мотивація підлітка до нього, можлива протидія дорослому втягувачу;

8) обставини знайомства 3 дорослим злочинцем (місце, час, свідки тощо); мотив знайомства, характер взаємовідносин (можливе спільне 
вживання алкоголю, наркотиків тощо, у тому числі, матеріальні можливості й місце діяння)

9) освіченість дорослого про неповнолітній вік підлітка (за зовнішнім виглядом, манерами поведінки, за досвідом спілкування 3 ним, батьками, друзями, сумісному проведенні вільного часу, навчанні), обізнаність дорослого втягувача про вік підлітка, його місце проживання, навчання, його родину та інші обставини.

Якщо має місце інформація про те, що неповнолітній є членом злочинної групи або секти, слідчий повинен з'ясувати такі питання:

1) склад групи, місця зустрічей членів групи; по кожному із них - місце проживання й навчання чи роботи; його батьки, родичі, друзі (у тому числі за межами групи); наявність у групі дорослих осіб (їх характеристика);

2) взаємовідносини в групі, можливі протиріччя в ній;

3) мета існування групи (захист від інших угруповань, для вчинення злочинів тощо);

4) зміст протиправної діяльніості групи і ії членів (вид і спосіб вчинення злочинів, наявність зброї тощо).

При знаходженні неповнолітнього в складі злочинної групи підвищується ймовірність того, що він буде протидіяти розслідуванню. Особливу складність набувають випадки, коли неповнолітні є членами різного роду релігійних організацій деструктивного характеру, втягненими у їх лави з використанням різноманітних видів обману і технік контролю свідомості. Ступінь контролю свідомості окремих осіб може досягати такого стану, що колишня особистісна ідентифікація стирається, доводиться до стану психічної неспроможності, що потребує врахування під час допиту таких неповнолітніх.

При наявності в групі внутрішніх протиріч і конфліктів, слідчий може використовувати це при виборі тактичних прийомів допиту неповнолітнього у випадку, якщо той обрав по справі конфліктну позицію. У такій ситуації слідчий повинен докласти зусиль для з'ясування функцій управління групи (організації), рольової діяльності кожного їі члена (включаючи самого неповнолітнього).

У науковій літературі висловлюються рекомендації про безумовну необхідність переносу допиту неповнолітнього, для того щоб зняти стан збудження, який може мати місце, насамперед у провадженнях про вбивство, тяжкі тілесні ушкодження та інші злочини, коли неповнолітній надзвичайно приголомшений вчиненим і потрібен деякий час, щоб минуло збудження $[16$, с. 66]. У той же час інші дослідники навпаки рекомендують негайно проводити допит неповнолітнього (особливо підозрюваного), оскільки у випадку відкладеного допиту дорослі втягувачі, співучасники й інші зацікавлені особи, використовуючи підвищену навіюваність неповнолітнього, можуть впливати на нього, у тому числі вмовити його взяти вину на себе $[17$, с. 338]. На наш погляд, друга рекомендація є більш доцільною, що підтверджується й результатами узагальнення нами емпіричних даних, де переважна кількість опитуваних слідчих висловила думку, що допитувати неповнолітнього потрібно як найшвидше після 
встановлення його причетності до вчинення злочину, до якого він був втягнений. Інша справа, що під час допиту слідчий повинен допомогти підлітку подолати збуджений стан, який заважає отримати від нього об'єктивну інформацію. Тим більше, що криміналістикою розроблені різноманітні прийоми «зняття напруги» на допиті [18, с. 92]. При цьому потрібно враховувати, що повна відсутність психічної напруги на допиті може привести до виникнення почуття безкарності і безвідповідальності в неповнолітнього, що також неприпустимо [19, с. 110].

Найчастіше саме перший допит неповнолітнього дає найповнішу інформацію як про обставини вчиненого неповнолітнім злочину, так і обставини його втягнення.

Традиційно допит поділяють на чотири етапи: а) встановлення психологічного контакту; б) вільна розповідь; в) постановка запитань; г) ознайомлення з протоколом допиту і його підписання. Розглянемо окремі з них.

Встановлення слідчим психологічного контакту з неповнолітнім $\epsilon$ необхідною передумовою досягнення мети допиту [20, с. 106; 21, с. 185] Незважаючи на неоднозначне тлумачення юристами поняття «психологічний контакт», більшість із них визнає, що його метою $є$ створення сприятливої обстановки з метою отримання слідчим потрібної інформації [22, с. 98; 20, с. 100]. Так Г. О. Зорін відзначає схильність неповнолітніх (віком 12-15 років) до «претензій на дорослість»: він рекомендує слідчому в процесі формування психологічного контакту 3 неповнолітнім потерпілим похвалити його зовнішність і міркування, говорити з ним як 3 дорослою людиною [23, с. 300]. У свою чергу С. С. Центров [13, с. 137] взагалі обгрунтовує необхідність встановлення психологічного контакту не тільки з метою одного чи двох допитів, але й на весь період слідства.

Ще однією тактичною особливістю допиту неповнолітнього $є$ максимальне використання можливостей вільної розповіді. Остання дозволяє не тільки отримувати потрібну інформацію по кримінальному провадженню, але і виявляти можливі обмовки і протиріччя, а також уникати навіювання на допитуваного. Однак неповнолітні не завжди можуть дати розгорнуту інформацію, як через незначний життєвий досвід, так і внаслідок недостатньої розвиненості логічного мислення, у зв' язку з чим важливого значення набуває стадія допиту «питання-відповідь» [24]. 3 урахуванням викладеного, потрібно ретельно продумати зміст і форму питань; вони повинні бути чіткими, ясними, зрозумілими для його віку і не носити характеру навідних. Тактика допиту неповнолітнього повинна бути направлена не тільки на отримання повної й правдивої інформації про його втягнення в злочинну діяльність, але й тих можливих доказів, які можуть підтвердити його свідчення. Непідтвердження свідчень неповнолітнього іншими доказами при подальшій їх можливій зміні в суді часто приводить до припинення кримінального переслідування втягувача або його виправдання. 
Важливою складовою діяльності слідчого є правильне визначення тактичних завдань, пошук і вибір тактичних засобів їх вирішення. Викладене стосується, у тому числі, вибору відповідних тактичних прийомів, їх комбінацій і тактичних операцій. Важливою умовою вирішення тактичних завдань допиту $є$ його якісна попередня підготовка, основана на використанні наявної інформації по справі і врахуванні особистості неповнолітнього. Зокрема наявність у неповнолітнього психологічного розладу, затримки розвитку тощо повинні враховуватися при обранні напрямку тактичного впливу на нього.

До переліку дискусійних належать питання про межі допустимості тактичного впливу на особистість неповнолітнього. Насамперед це стосується тактики його допиту в конфліктній ситуації. У зв'язку з цим необхідно висловити наступні рекомендації: якщо відомо, що неповнолітній обрав конфліктну позицію, необхідно спочатку нейтралізувати його негативну установку. Слід мати на увазі, що неправду легше попередити, ніж викрити. Зокрема можливе звернення до позитивних якостей особи неповнолітнього, заклик до почуття совісті, чесності тощо. Вважається, що слідчий може використовувати весь арсенал розроблених криміналістикою допустимих тактичних засобів впливу на неповнолітнього, але за умови врахування особливостей, притаманних цій категорії допитуваних. Так у літературі обгрунтовано зазначається більш висока ефективність застосування тактичних прийомів емоційного впливу на неповнолітніх при викритті їx у неправдивих свідченнях, оскільки засоби логічного переконання можуть бути малоефективними як внаслідок нерозуміння допитуваного самого факту викриття, так і в силу «духу протиріччя», який притаманний дітям і призводить до упертого повторювання ними явно безглуздої брехні [20, с. 123]. Разом із тим існує проблема допустимого застосування по відношенню до неповнолітніх тактичних прийомів розв' язання конфліктних ситуацій допиту, основаних на використанні так званих «слабких місць» у психіці допитуваного: жадібності, почутті помсти, ревнощів та ін. Вважається, що застосування подібних прийомів по відношенню до неповнолітніх молодших вікових груп неприпустимо. Це пов' язано з тим, що, окрім з'ясування обставин, що підлягають доказуванню по кримінальному провадженні, слідчому, у процесі допиту неповнолітнього, не можна випускати з виду і виховний момент [14], а також, по можливості, сприяти пом'якшенню негативного впливу обстановки допиту на нестійку (хитку) психіку неповнолітнього [25, с. 131]. Слідчий не повинен своїми діями чинити вплив на негативні сторони особистості неповнолітнього, тим самим розвиваючи їх далі. Більш того, застосування таких прийомів по відношенню до неповнолітніх може призвести їх до обмови або самообмови.

Висновки. Таким чином, врахування процесуальних особливостей та криміналістичних рекомендацій проведення допиту неповнолітніх, що втягнені в злочинну діяльність, є базовою основою для слідчого на отримання позитивного результату під час проведення згадуваної слідчої (розшукової) дії. 


\section{Використані джерела:}

1. Шепітько В. Ю. Допит потерпілого: тактико-психологічний підхід / В. Ю. Шепітько // Питання боротьби зі злочинністю. - 2008. - Вип. 15. C. $256-265$.

2. Одерій О. В. Теорія і практика розслідування злочинів проти довкілля: монографія / О. В. Одерій. - Х.: Діса плюс, 2015. - 528 с.

3. Тертишник В. М. Кримінально-процесуальне право України: підручник. 4-те вид. - К.: А.С.К., 2003. - 1120 с.

4. Кузнецова С. В. Тактика допроса несовершеннолетних / С. В.Кузнецова, Т. С. Кобцова. - М.: Экзамен, 2004. - 96 с.

5. Конвенція про права дитини: прийнята 20 листоп. 1989 р.; ратифік. Україною 27 лют. 1991 p. URL: http: // zakon.rada.gov.ua/cgi- bin/laws/main. Cgi? nred $=9923.091$

6. Про охорону дитинства: Закон України від 26 квіт. 2001 р. № 2402-III, ред. станом на 07 трав. 2017 р. // Відомості Верховної Ради України. 2001. № 30. Ст. 142. URL: http://zakon5.rada.gov.ua/laws/show/2402-14

7. Кримінальний процесуальний кодекс України: наук.-практ. комент.: у 2 т. за заг. ред.: В. Я. Тацій, В. П. Пшонка, А. В. Портнов. Харків: Право, 2012. Т. 1. 767 с.

8. Цивільний кодекс України: від 16 січ. 2003 р. № 435-IV, ред. станом на 19 лип. 2017 р. // Відомості Верховної Ради України. 2003. № 40-44. Ст. 356. URL: http:/ / zakon2.rada.gov.ua/laws/show/2341-14

9. Видюк А. В. Гарантії прав малолітніх і неповнолітніх учасників криінального провадження під час допиту/ А. В. Видюк // Вісник кримінального судочинства. - 2018. - Вип. 1. - С. $123-131$.

10. Навроцька В. В. Вік набуття кримінально-процесуальної дієздатності. Часпис Академії адвокатури України: електрон. фахове вид. 2010. № 6 URL: http:/ / e-pub.aau.edu.ua/index.php/chasopys/article/view/582/602 (дата звернення 10.02.2019).

11. Дяченко К. І., Шость Н. В. Процесуальні особливості розслідування справ про злочини неповнолітніх: метод. посіб. Харків: Константа. - 1997. - 56 с.

12. Романюк В. В. Деякі особливості допиту неповнолітнього підозрюваного у кримінальному провадженні / В. В.Романюк // Право і безпека. - 2016. - № 4(63). - С. 81-85.

13. Центров Е. Е. Криминалистическое учение о потерпевшем / Е. Е. Центров. - Москва, 1988. - 230 с.

14. Порбов Н. И. Тактика допроса на предварительном следствии: [учебное пособие] / Н. И. Порубов. - М.: Изд-во БЕК, 1998. - 208 с.

15. Руководство для следователей / Под общ. ред. В. В. Мозякова. - М.: Экзамен, 2005 - 912 с.

16. Каневский Л. Л. Расследование и профилактика преступлений несовершеннолетних / Л. Л.Каневский. - М.: Юрид. лит., 1982. -111 с.

17. Гаврилин, Ю. В. Криминалистика: методика расследования отдельных видов преступлений: курс лекций / Ю. В. Гаврилин, Н. Г. Шурухнов. - М.: Книжный мир, 2004. - 471 с.

18. Подшибякин А. С. Допрос как разновидность общения // Актуальные проблемы криминалистики на современном этапе. Материалы Всероссийской 
научно-практической конференции. Краснодар, 23-24 мая 2002 г. - Краснодар: КГАУ, 2002. - С. 91-98

19. Макаренко И. А. Некоторые проблемы психологического воздействия на несовершеннолетних обвиняемых в процессе расследования уголовных дел // Актуальные проблемы криминалистики на современном этапе. Материалы Всероссийской научно-практической конференции. Краснодар, 23-24 мая 2002 г. Краснодар: КГАУ, 2002. - С.110

20. Белкин Р. С. Тактика следственных действий / Р.С.Белкин, Е. М. Лившиц . - М.: Новый Юрист, Право и Закон, 1997. - 176 с.

21. Одерий А. В. Тактики допроса свидетелей на досудебном расследовании экологических преступлений (отдельные аспекты) / А. В. Одерий // Вісник Маріупольського державного університету. - 2012. - Вип. 3-4. - С. 183-188.

22. Комиссаров В. И. Тактика допроса потерпевших от преступлений, совершаемых организованными группами лищ / В.И.Комиссаров, О.А. Лакаева. М.: Юрлитинформ, 2004. - 160 с.

23. Зорин, Г. А. Руководство по тактике допроса: учеб.-практ. пособие / Г. А. Зорин. - М.: Юрлитинформ, 2001. - 320 с.

24. Каневский Л. Л. Тактика допроса свидетелей по делам несовершеннолетних // Теоретические проблемы криминалистической тактики. Межвуз. сб. научн. тр. - Свердловск: Свердл. юрид. инст-т, 1981. - С.104

25. Усманов У. А. Тактика допроса на предварительном следствии: Справочник / У.А. Усманов. - М.: “Издательство ПРИОР”, 2001. - 176 с.

\section{References}

1.Chepitko V. Y. (2008). Dopit poterpilogo: taktiko-psijologichniy pidjid/ V. Y. Chepitko// Pitanna borotbi zi zlochinnistu.- Vip.15. [in Ukrainian]

2. Oderiy O. V. (2015). Teoriya i practica rozsliduvanna zlochiniv proti dovkilla: monografia / J.: Disa plus. [in Ukrainian]

3. Tertichnik V. M. (2003). Kriminalno-procesualne pravo Ukrain: pidruchnik - K.: A.C.K. [in Ukrainian]

4. Kuznecova S. V., Kobcova T. C. (2004). Taktika doprosa nesoverchennoletnij. - M.: Examen.

5. Convenciya pro prava ditini: priynata 20.11.1989.; ratific. Ukrain 27.02.1991

6. Pro ojoronu ditinstva: Zakon Ukrain vid 26.04.2001. №2402-III // Vidomosti Verjovnoyi Radi 2001. № 30. St.142.

7. Kriminalniy-procesualniy kodeks Ukrain: nauk.-pract. coment.: za red. Taciy V. Y, Pchonka V. P., Portnov A. V. Jarki : Pravo.

8. Civilniy kodeks Ukrain: vid 16.01.2003. № 435-IV // Vidomosti Verjovnoyi Radi 2003 № 40-44. St.356.

9. Viduk A. V. (2018). Garantii prav malolitnij i nepovnolitnij uchasnikiv kriminalnogo provadgenna// Visnik kriminalnogo sudochinstva.

10. Navrocka V. V. (2010). Vik nabutta kriminalno-procesualnoyi diezdatnosti. Chasopis Akademi advokaturi Ukrain: electr. Fajove vid. 2010.- № 6.

11. Diachenko K. I., Chost N. V. (1997). Procesualni osoblivosti rozsliduvanna sprav pro zlochini nepovnolitnij: metod. posib. Jarkiv: Konstanta.

12. Romanuk V. V. (2016). Deyaki osoblivosti dopitu nepovnolitniogo pidozruvanogo u kriminalnomu provadgenni / / Pravo i bezpeka. - 2016. - № 4(63).

13. Centrov E. E. (1988). Kriminalisticheskoe uchenie o poterpevchem. Moskva. 
14. Porubov N. I. (1998). Taktika doprosa na predvaritelnom sledstvii: [uchebnoe posobie] -- M.: izdatelstvo BEK.

15. Rukovodstvo dla sledovateley / pod red. Mozakova V. V. (2005). - M.: Examen.

16. Kanevskiy L. L. (1982). Rassledovanie i profilaktika prestupleniy nesoverchennoletnij. - M.: Yurid. lit.

17. Gavrilin Y. V., Churujnov N. G. (2004). Kriminalistika: metodika rassledovaniya otdelnij vidov prestupleniy. - M.: Knigniy mir.

18. Podchibakin A. S. (2002). Dopros kak raznovidnost obcheniya // Aktualnie problem kriminalistiki na sovremennom etape. Materiali Vserossiyskoy nauchnoprakticheskoy konferencii. Krasnodar.

19. Makarenko I. A. (2002). Nekotorie problem psijologicheskogo vozdeystviya na nesoverchennoletnij obvinaemij v processe rassledovaniya ugolovnij del // Aktualnie problem kriminalistiki na sovremennom etape. Materiali Vserossiyskoy nauchnoprakticheskoy konferencii. Krasnodar.

20. Belkin R. S., Livchic E. M. (1997). Taktika sledstvennij deystviy. - M.: Noviy yurist, Pravo i Zakon.

21. Oderiy O.V. (2012). Taktika doprosa svideteley na dosudebnom rassledovanii ekologicheskij prestupleniy (otdelnie aspekti) // Visnik Mariupolskogo dergavnogo universitetu. - Vip. 3-4.

22. Komissarov V. I., Lakaeva O. A. (2004). Taktika doprosa poterpevchij ot prestupleniy, soverchaemij organizovannimi gruppami lic. - M.: Yurlitinform.

23. Zorin G.A. (2001). Rukovodstvo po taktike doprosa: ucheb.-prakt. posobie. - M.: Yurlitinform.

24. Kanevskiy L. L. (1981). Taktika doprosa svideteley po delam nesoverchennoletnij//Teoreticheskie problem kriminalisticheskoy taktiki. Megvuz. Sb. Nauchnij trudov. - Sverdlovsk: Sverdlovskiy yurid. institut.

25. Usmanov U. A. (2001). Taktika doprosa na predvaritelnom sledstvii: Spravochnik. - M.: «Izdatelstvo PRIOR».

Стаття надійшла до редколегї 28.05.2019

Готвянская М. А ., аспирантка Донецкого юридического института МВД Украины (г. Кривой Рог, Украина)

\section{ТАКТИКА ДОПРОСА НЕСОВЕРШЕННОЛЕТНЕГО, ВОВЛЕЧЕННОГО В ПРЕСТУПНУЮ ДЕЯТЕЛЬНОСТЬ (ОТДЕЛЬНЫЕ АСПЕКТЫ)}

В статье рассматриваются отдельные аспекты тактики допроса несовершеннолетнего, вовлеченного в преступную деятельность. Акцентировано внимание на процессуальных особенностях допроса несовершеннолетнего лица, освещены проблемы, с которыми сталкиваются практики, предложены пути их решения. Указано на важность подготовительного этапа допроса, изложены тактические особенности установления психологического контакта с несовершеннолетним, обоснована рекомендация максимально использовать возможности свободного рассказа. Обращено внимание на роль криминалистических рекомендаций во время допроса. 
Ключевые слова: уголовное производство, тактика допроса несовершеннолетнего, взрослый, криминалистические рекомендации, вовлечение в преступную деятельность.

Hotvyanska M., graduate student of Donetsk law institute of the ministry of snternal affairs of Ukraine. (Krivoy Rog, Ukraine)

\section{TACTICS OF INTERROGATION OF A MINOR INVOLVED IN CRIMINAL ACTIVITY (CERTAIN ASPECTS)}

The article discusses certain aspects of the interrogation tactics of a minor involved in criminal activities. The attention is focused on the procedural peculiarities of the interrogation of a minor, highlights the problems faced by the practitioners, suggested ways to solve them. Based on the study, the author gives a tactical recommendation related to the expediency of urgent interrogation of a minor (especially a suspect), because in the case of deferred interrogation accomplices, other interested people can negatively influence him, including convincing him to take the blame. The importance of the preparatory stage of interrogation was pointed out, the tactical features of establishing psychological contact with a minor were outlined, the recommendation was grounded to maximize the use of the possibilities of a free story. Attention is drawn to the role of forensic recommendations during interrogation. It is emphasized that the question of the limits of admissibility of a tactical impact on the personality of a minor is among the discussion ones. This problem is particularly acute in the context of a conflict situation. In such cases, it is recommended to neutralize the negative attitudes of the minor. At the same time, the investigator should not by his actions influence the negative sides of the minor. It is marked that a teacher or psychologist have a right with permission an investigator to be set by a question to minor, and on completion of interrogation to meet with protocol and lay out a remark about a rightness and plenitude of records in him, about what straight certainly in ч. 2 ст. 227 КПК of Ukraine. At the same time, for the sake of minimization (or doing impossible) of negative influence on minor, it is expedient in advance to discuss an investigator with persons that take part in drunk up, general tactical plan, role and degree of their participating in drunk up minor, including, impermissibility of raising questions, instructive intonation, irritation and other. Paid attention, that to the number of debatable a question behaves about the limits of admission of tactical influence on personality minor. First of all, it touches tactics of his interrogation in a conflict situation. Necessary recommendations are given in this connection. It is considered that an investigator can use all arsenal of worked out criminalistics of possible tactical facilities of influence on minor, but on condition of taking into account of features inherent to this category of interrogated.

Moreover, the use of such methods in relation to a minor can lead the latter to a slander or self-incrimination.

Key words: criminal proceedings, interrogation tactics of a minor, adult, criminalistics recommendations, involvement in criminal activity. 